\title{
PENGETAHUAN MAHASISWI AKBID ANDI MAKKASAU TENTANG PENUNDAAN PEMOTONGAN TALI PUSAT PADA BAYI BARU LAHIR DI AKADEMI KEBIDANAN ANDI MAKKASAU PAREPARE TAHUN 2016
}

\author{
Arifa Usman \\ arifa.cube@gmail.com
}

\begin{abstract}
ABSTRAK
Menurut WHO pada manajemen fisiologis ini, waktu yang optimal untuk pengkleman dan pemotongan tali pusat semua bayi tanpa memandang usia kehamilan atau berat badan janin adalah ketika sirkulasi atau denyutan di tali pusat telah berhenti dan tali pusat terlihat mendatar sekitar 3 menit atau lebih. (Depkes RI)

Tujuan dalam penelitian ini untuk mengetahui pengetahuan bidan tentang penundaan pemotongan tali pusat pada bayi baru lahir di akademi kebidanan andi makkasau kota parepare tahun 2016

Jenis penelitian yang dilakukan adalah penelitian dengan pendekatan deskriptif dengan populasi semua mahasiswi tingkat II yang ditemui di Akbid andi makkasau parepare sebanyak 195 orang dan terdapat 30 orang sampel yaitu 15 orang mahasiswi dari tingkat II dan 15 orang mahasiswi dari tingkat III

Dari hasil penelitian yang telah dilaksanakan menunjukkan bahwa pengetahuan mahasiswi Akbid andi makkasau tentang penundaan pemotongan tali pusat pada bayi baru lahir di akademi kebidanan andi makkasau kota parepare tahun 2016 sebanyak 4 orang $(13,33 \%)$ yang mempunyai pengetahuan baik, yang terdiri dari 1 orang dan 10 orang $(33,33 \%)$ tingkat II dan 3 orang (10\%) tingkat III dan mempunyai pengetahuan kurang sebanyak 11 orang $(36,66)$ yang terdiri dari 9 orang $(30 \%)$ tingkat 2 dan 3 orang $(6,66)$ tingkat 3

Diharapkan dapat sebagai bahan kajian terhadap teori yang telah diperoleh mahasiswi selama mengikuti pembelajaran serta diharapkan dapat menambah dan meningkatkan pengetahuan tentang penundaan pemotongan tali pusat pada bayi baru lahir

Kata Kunci : : Pengetahuan Penundaan Pemotongan Tali Pusat
\end{abstract}




\section{PENDAHULUAN}

Tali pusat merupakan penghubung antara bayi dengan plasenta ibu. Tali pusat berfungsi untuk menyalurkan nutrisi penting serta oksigen dari ibu kejanin. Setelah persalinan, rata-rata, plasenta dan tali pusat akan lepas dengan sendirinya dari tubuh ibu dalam waktu 10 hari

Delayed cord clamping adalah praktek penundaan pengkleman dan pemotongan tali pusat tidak dijepit atau dipotong sampai setelah denyutan berhenti, atau sampai setelah plasenta lahir seluruhnya. (Clamping Cord. 2015)

Target AKI di indonesia pada tahun 2015 adalah 102 kematian per 100.000 kelahiran hidup. Sementara itu berdasarkan Survey Demografi dan kesehatan Indonesia (SDKI) tahun 2012, Angka kematian ibu (AKI) (yang berkaitan dengan kehamilan, persalinan, dan nifas) sebesar 359 per 100.000 kelahiran hidup. Angka ini masih cukup jauh dari target yang harus dicapai pada tahun 2015.

Angka kematian ibu di sulawesi selatan pada tahun 2009 sebanyak 143 orang atau 92,89 per 100.000 kelahiran hidup, tahun 2010 jumlah kematian ibu mengalami penurunan menjadi 121 orang atau 85,17 per 100.000 kelahiran hidup. Angka ini masih cukup jauh dari target yang harus dicapai pada tahun 2015. (Data Statistic Indonesia. 2015)

Angka kematian ibu di sulawesi selatan pada tahun 2009 sebanyak 109 per 100.000 kelahiran hidup dan meningkat pada tahun 2009 sebanyak 115 per 100.000 kelahiran hidup. (Dinkes Kota Parepare. 2015)

Waktu yang paling kritis untuk mencegah perdarahan postpartum adalah ketika plasenta lahir dan segera setelah itu, manajemen aktif kala III mempercepat kelahiran plasenta dan dapat mencegah dan mengurangi perdarahan postpartum. Manajeman aktif kala III telah dimasukkan kedalam asuhan persalinan normal (APN) dengan mengklem tali pusat dan menyuntikkan oksitosin 10 UI 2 menit setelah bayi lahir (Saifuddin, 2007)

Pemotongan tali pusat dalam proses persalinan akan menghentikan penyaluran darah dan oksigen dari plasenta yang sesungguhnya masih berlangsung meski bayi sudah dilahirkan.

Menurut Menurut WHO pada manajemen fisiologis ini, waktu yang optimal untuk pengkleman dan pemotongan tali pusat semua bayi tanpa memandang usia kehaamilan atau berat badan janin adalah ketika sirkulasi atau denyutan di tali pusat telah berhenti dan tali pusat terlihat mendatar sekitar 3 menit atau lebih setelah bayi lahir (Riksani, 2012)

Selain manajemen aktif kala III ada juga yang disebut manajemen fisiologis persalinan kala III atau penundaan pengkleman tali pusat sampai tali pusat berhenti berdenyut. Menurut WHO pada manajemen fisiologis ini, waktu yang optimal untuk pengkleman dan pemotongan tali pusat semua bayi tanpa memandang usia kehaamilan atau berat badan janin adalah ketika sirkulasi atau denyutan di tali pusat telah berhenti dan tali pusat terlihat mendatar sekitar 3 menit atau lebih setelah bayi lahir (Riksani, 2012)

Dalam suatu penelitian yang penelitinya tidak disebutkan oleh WHO, review meliputi 11 percobaan, meneliti perbedaan antara penjepitan dan pemotongan tali pusat yang dini dan 
tertunda dalam hal resiko perdarahan postpartum. Tidak ada perbedaan yang signifikan antara dua kelompok tersebut. Namun ada juga fakta yang menyebutkan bahwa penjepitan tali pusat langsung atau segera setelah bayi lahir dapat meningkatkan resiko perdarahan pasca melahirkan dan retensi plasenta dikarenakan oleh engorging plasenta dengan darah bayi. Hal ini membuat lebih sulit bagi rahim berkontraksi dan melapaskan plasenta. (Baston \& Hall, 2012)

Robin Lim mengatakan, penundaan pemotongan tali pusar bertujuan memaksimalkan aliran oksigen dan sel nutrisi, serta menghindari trauma pada bayi akibat transisi kehidupan yang terlalu drastic. Setelah lahir, tali pusat bayi juga tidak langsung dijepit dan digunting. Ia menunda pemotongannya selama minimal 1 jam

Peran oksigenasi dari plasenta ke paru-paru bayi mengalami peralihan pada masa setelah bayi lahir dan sebelum plasenta dilahirkan. Selama masa tersebut, oksigenasi bayi melalui plasenta masih berjalan dan darah masih ditransfusikan ke bayi. Hal tersebut dapat mempengaruhi hemoglobin $(\mathrm{Hb})$, hematokrit $(\mathrm{Ht})$, menambah volume darah dan mencegah hipovolemi serta hipotensi pada bayi baru lahir. Adanya perbedaan waktu pemotongan tali pusat antara penundaan pemotongan tali pusat dan pemotongan tali pusat segera, mempengaruhi hematologi bayi baru lahir cukup bulan, namun waktu pemotongan tali pusat yang bermanfaat bagi bayi baru lahir masih diperdebatkan.

Studi tentang pengetahuan penundaan pemotongan tali pusatpada bayi baru lahir diharapkan dapat lebih menambah pengetahuan mahasiswi / calon bidan dalam upaya mencegah anemia sedini mungkin dan mencegah munculnya penyakit lain yang disebabkan oleh anemia itu sendiri.

Dari latar belakang diatas sehingga peneliti tertarik untuk meneliti tentang pengetahuan mahasiswa AKBID andi Makkasau parepare tentang penundaan pemotongan tali pusat pada bayi baru lahir di Akademi Kebidanan Andi Makkasau Parepare.

\section{Rumusan Masalah}

\section{Tujuan umum}

Untuk mengetahui pengetahuan mahasiswi AKBID Andi Makkasau tentang penundaan pemotongan tali pusat pada bayi baru lahir di Akademi kebidanan andi makkasau parepare tahun 2016

\section{Tujuan Khusus}

a. Diketahuinya pengetahuan mahasiswi AKBID Andi makkasau tentang penundaan pemotongan tali pusat menurut mahasiswi tingakt II semester IV di akademi kebidanan andi makkasau parepare tahun 2016

b. Diketahuinya pengetahuan mahasiswi AKBID Andi makkasau tentang penundaan pemotongan tali pusat menurut mahasiswi tingakt III semester VI di akademi kebidanan andi makkasau parepare tahun 2016 


\section{METODE PENELITIAN}

A. Jenis Penelitian

Desain penelitian merupakan rencana penilitian yang disusun sedemikian rupah sehingga penelitian memperoleh jawaban terhadap pertannyaan penelitiannya. Berdasarkan tujuan penelitian yang digunakan adalah bersifat deskriptif.

\section{B. Lokasi dan Waktu Penelitian}

1. Lokasi penelitian dilaksanakan di Kampus Akademi Kebidanan Andi Makkasau Parepare tahun 2016.

2. Waktu

Waktu penelitian dilaksanakan mulai tanggal 13 - 26 juli 2016.

\section{Populasi dan Sampel}

1. Populasi penelitian

Yang menjadi Populasi dalam penelitian ini adalah Mahasiswi Akademi Andi Makkassau Parepare tingkat II dan III.

2. Sampel Penilitian

Adapun jumlah sampel dalam penelitian ini adalah 30 orang. 15 orang dari tingkat II dan 15 orang dari tingkat III.

3. Besarnya Sampel

Seluruh populasi yang ada sejumlah 30 mahasiswi D3 Kebidanan di Akbid Andi Makkasau parepare.

\section{Tehnik Pengolahan Data}

Pengolahan dan Penyajian Data

Data di olah secara manual menggunakan kalkulator yang disajikan dalam bentuk distribusi prekuensi dan presentasi yang dilengkapi dengan penjelasan-penjelasan pada table.

\section{Editing}

Editing adalah upayah untuk melakukan pemeriksaan terhadap kelengkapan dan kejelasan jawaban kuensioner dan penyesuaian data yang diperoleh dengan kebutuhan peneliti hal ini dilakukan di lapangan sehingga apabila terdapat data yang meragukan ataupun salah maka akan dijelaskan ke responden.

2. Coding

Coding merupakan kegiatan pemberian kode numeric pada data yang terdiri atas beberapa kategori untuk masing-masing kelas terhadap data yang diperoleh dan sumber data yang telah diperiksa kelengkapannya.

3. Entry

Data Entry adalah kegiatan memasukan data yang telah dikumpulkan ke dalam master atau data base computer.

4. Cleansing (Pemberian data) 
Data yang telah diperiksa kelengkapan dan kebenarannya. Merupakan kegiatan pengecekan kembali data yang dimasukan dilakukan bila tedapat kesalan dalam memasukan data yaitu dengan meliha distribusi prekuensi dari variabel-variabel yang ditelitih.

Analisa Data

Pengolahan data dilakukan secara manual untuk mengetahui gambaran pengetahuan mahasiswi AKBID di akademi kebidan Andi makkasau parepare tahun 2016.

Adapun utuk pengolahan data pengetahuan menggunakan presentase dengan

Rumus :

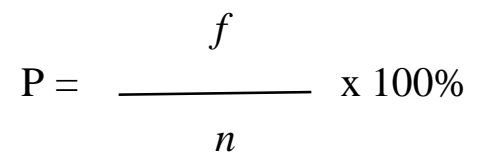

Keterangan :

$\mathrm{P}=$ persentase yang dicari

$f=$ frekuensi distribusi

$n=$ jumlah sampel

pengambilan kesimpulan hasil penelitian dihitung rata-rata persentase penilaian setiap indicator dengan criteria apabila menjawab benar $<60 \%$ atau $1-9$ dari jumlah pernyataan dikategorikan pengetahuan, apabilah menjawab 66,66-73,33\% atau $10-11$ dari jumlah pernyataan dikatakan pengetahuan baik

Hasil penelitian

\section{HASIL DAN PEMBAHASAN}

Penelitian ini dilaksanakan pada mahasiswi tingkat II dan III Akademi Kebidanan Andi Makkasau Parepare.

Pengambilan Data Selanjutnya Data diolah secara manual dan dilanjutkan dengan menggunakan computer kemudian dianalisa secara deskriptif. Hasil pengolahan data disajikan dalam bentuk table distribusi prekuensi disertai penjelasan. 
Table I :

Distribusi frekuensi Pengetahuan Mahasiswi AKBID Andi Makkasau Tentang PenundaanPemotongan Tali Pusat Pada Bayi Baru Lahir di AKBIDAndi Makkasau Parepare Tahun 2016

\begin{tabular}{|c|c|c|c|c|c|c|c|}
\hline \multirow{3}{*}{ No } & \multirow{3}{*}{ Pengetahuan } & \multicolumn{4}{|c|}{ Tingkat } & \multirow{3}{*}{$\mathbf{F}$} & \multirow{3}{*}{$\%$} \\
\hline & & \multicolumn{2}{|c|}{ Tingkat II } & \multicolumn{2}{|c|}{ Tingkat III } & & \\
\hline & & $\mathbf{F}$ & $\%$ & $\mathbf{F}$ & $\%$ & & \\
\hline 1 & Baik & 1 & 3,33 & 3 & 10 & 4 & 13,33 \\
\hline 2 & Cukup & 5 & 16,66 & 10 & $\begin{array}{l}33,3 \\
3\end{array}$ & 15 & 50 \\
\hline 3 & Kurang & 9 & 30 & 2 & 6,66 & 11 & 30,67 \\
\hline & Jumlah & 15 & 50 & 15 & 50 & 30 & 100 \\
\hline
\end{tabular}

Sumber : data primer 2016

Dari data table 1 diatas distribusi Gambaran pengetahuan Mahasiswi AKBID tentang penundaan pemotongan Tali Pusat Pada Bayi Baru Lahir di Akademi Kebidanan Andi Makkasau Kota Parepare tahun 2016 sebanyak 4 orang ( 13,33 \% ) yang mempunyai pengetahuan baik, yang terdiri dari 1 orang ( $3,33 \%$ ) tingkat II dan 3 orang ( $10 \%$ ) tingkat III sebanyak 15 orang ( $50 \%$ ) yang mempunyai pengetahuan cukup, yang terdiri dari 5 orang $(16,66 \%)$ tingkat II dan 10 orang $(3,33)$ tingkat III. Dan yang mempunyai pengetahuan kurang sebanyak 11 orang $(36,66)$ yang terdiri dari 9 orang ( $30 \%)$ tingkat II dan 3 orang $(6,66)$ tingkat III.

Dari penelitian diatas dapat disimpulkan bahwa pengetahuan mahasiswi tingkat III lebih tinggi dibanding pengetahuan tingkat II.

Pembahasan Hasil Penelitian

Untuk mengetahui lebih lanjut hasil penelitian yang diperoleh setelah pengolahan, penyajian dan analisis data, maka akan dibahas sesuai dengan pariabel yang ditelitih, sebagai berikut :

\section{Pengetahuan}

Pengetahuan mahasiswi tentang penundaan pemotongan tali pusat pada bayi baru lahir.

Penelitian tingkat pengetahuan mahasiswi akademi kebidanan andi makkasau parepare, sebanyak 4 orang $(13,33 \%)$ yang mempunyai pengetahuan baik, yang terdiri dari 1 orang (3,33\%) tingkat II dan 3 orang (10\%) tingkat III sebanyak 15 orang (50\%) yang mempunyai pengetahuan cukup, yang terdiri dari 5 orang $(16,66 \%)$ tingkat II dan 10 orang $(33,33)$ tingkat III. Dan yang mempunyai pengetahuan kurang sebayak 11 orang $(36,66)$ yang terdiri dari 9 orang $(30 \%)$ tingkat II dan 2 orang $(6,66)$ tingkat III. Dari hasil penelitian ditemukan bahwa tingkat pengetahuan mahasiswi tingkat III lebih tinggi disbanding dengan pengetahuan mahasiswi tiangkat II. 


\section{KESIMPULAN}

Berdasarkan hasil penelitian tentang penundaan pemotongan tali pusat pada bayi baru lahir di akademi andi makkasau kota parepare tahun 2016 maka dapat di simpulkan sebagai berikut :

Respon yang mempunyai tingkat pengetahuan baik tentang penundaan pemotongan tali pusat pada bayi baru lahir sebanyak 4 orang $(13,33 \%)$ yang terdiri dari 1 orang $(3,33 \%)$ tingkat II dan 3 orang (10\%) tingkat III. Sebanyak 15 orang $(50 \%)$ yang mempunyai pengetahuan cukup, yang terdiri dari 5 orang $(16,66 \%)$ tingkat II dan 10 oarang $(33,33)$ tingkat III. Dan yang mempunyai pengetahuan kurang sebanyak 11 orang $(36,66)$ yang terdiri dari 9 orang $(30 \%)$ tingkat II dan 2 orang $(6,66)$ tingkat III.

Tingkat pengetahuan mahasiswi tingkat III lebih tinggi di banding dengan tingkat pengetahuan mahasiswi tingkat II. 


\section{DAFTAR PUSTAKA}

Amirudin, Ridwan. 2007. Studi Kasus Kontrol Faktor Biomedister Terhadap Kejadian Anemia Ibu Hamil. http://ridwanamirudin.wordpres.com. Diakses pada tanggal 25 juli 2016

Anonim. 2015. Hhtp://www.oufnchildrensshoppital diakses tanggal 15 juni 2016

Anonim. 2015. Hhtp:// www.Data Statis Indonesia.Com Diakses Tanggal 15 Juni 2016 Anonim. 2015. Hhtp://www.Who.Int. 2011 Diakses Tanggal 13 Juni 2016

Adila, L., Tari, N.R, Primantara, D. 2011. Perbandinagn Klem Tali Pusat Dini dan Lambat Pada Bayi Baru Lahir. Sari Pustaka, Unipersitas Padjajaran

Corwin, Elisabeth L. Buku Saku Patofisiologi Ed.3. Jakarta: EGC

Dewi, Vivian N. 2010. Asuhan Neonatal, Bayi, dan Balita. Jakarta: Salemba Medika

Hani, Ummi dkk. 2017. Asuhan Kebidanan Pada Kehamilan Fisiologis. Jakarta: Salemba Medika

Nelson, Waldo E.Ed. 2010. Ilmu Kesehatan Anak. Jakarta: Penerbit Buku Kedokteran. EGC

Prawihardjo, Sarwono. 2016. Ilmu Kebidanan. Jakarta: Yayasan Bina Pustaka 2008, Ilmu Kebidanan. Jakarta: Yayasan Bina Pustaka

Prawihardjo, Sarwono. 2010. Ilmu Kebidanan. Jakarta: PT Bina Pustaka Sarwono Prawirohardjo

Santosa, Qodri. 2008. Pengaruh Waktu Penjepitan Tali Pusat Terhadap Kadar Hemoglobin dan Hematokrit Bayi Baru Lahir. Tesis, Universitas di Ponegoro.

Sadikin. 2018. Buku Saku Perawatan Tali Pusat. Jakarta: EGC

Saifuddin, AB. 2007. Buku Ajar Maternal Neonatal. Jakarta: YBP-SP

Clamping cord.com Diakses Tanggal 15 Juni 2016

Dinkes Kota Parepare. Diakses Tanggal 15 Juni 2016

Dinkes Sulsel 2010. Diakses Tanggal 15 Juni 2016 